\title{
IMPLEMENTASI FATWA DSN-MUI NO: 77/DSN-MUI/V/2010 TERHADAP AKAD MURABAHAH PADA PRODUK CICIL EMAS DI BANK SYARIAH MANDIRI
}

\author{
Annas Syams Rizal Fahmi, Muhammad Irkham Firdaus, May Shinta \\ Retnowati dan Zulfatus Sa' diah ${ }^{1}$
}

\section{Abstrak}

Bank Syariah memiliki fungsi menghimpun dana dari masyarakat dalam bentuk titipan dan investasi dari pihak pemilik dana. Strategi baru telah dikembangkan dan diperkenalkan kepada industri perbankan syariah. Sebagai bentuk responden dari kebutuhan masyarakat tersebut, maka Bank Syariah memberikan jasa pelayanan kepada nasabah dalam bentuk jasa pelayanan keuangan untuk mengalihkan transaksi non Syariah (konvensional) yang telah berjalan menjadi transaksi yang sesuai dengan Syariah dengan memberikan jasa pembiayaan produk cicil emas yang di dasarkan dengan landasan hukum pada Fatwa Dewan Syariah Nasional. Dalam penelitian ini penulis membahas Analisis Pembiayaan Murabahah pada Produk Cicil Emas ditinjau dari Penerapan Fatwa DSN MUI No: 77/DSN-MUI/V/2010. Sehingga diharapkan mampu mengetahui bagaimana konsep mekasime penerapan akad dalam melakukan pembiayaan produk cicil emas dan juga landasan Fatwa DSN MUI. Pada penelitian ini penulis menggunakan metode kualitatif. Adapun untuk mendapatkan data-data pegawai dan nasabah yang melakukan pembiayaan produk cicil emas, penulis melakukan 3 cara yaitu dengan menggunakan observasi, wawancara dan dokumentasi, data yang terhimpun kemudian dianalisis dengan menggunakan metode analisis deskriptif. Hasil penelitian ini menunjukan bahwa praktik pembiayaan murabahah pada produk cicil emas di Bank Syariah Mandiri Kantor Cabang Pembantu Ponorogo sudah sesuai dengan fatwa DSN MUI No: 77/DSN-MUI/V/2010 tentang jual beli emas secara tidak tunai. Faktanya dalam praktik cicil emas pada Bank Syariah Mandiri Kantor Cabang Pembantu Ponorogo harga emas tidak bertambah selama akad berlangsung meskipun ada perpanjangan waktu setelah jatuh tempo, emas dijadikan jaminan dengan akad rahn dan disimpan di Bank Syariah Mandiri Kantor Cabang Pembantu Ponorogo, emas yang dijadikan jaminan tidak berubah akad dan tidak berpindah kepemilikan dan tetap disimpan di brankas Bank Syariah Mandiri Kantor Cabang Pembantu Ponorogo.

Kata Kunci: Fatwa DSN MUI, Pembiayaan Murabahah, Produk Cicil Emas.

${ }^{1}$ Prodi Hukum Ekonomi Syariah, Fakultas Syariah, Universitas Darussalam (UNIDA) Gontor.

Email: annassyams@unida.gontor.ac.id

IMPLEMENTASI FATWA DSN-MUI NO: 77/DSN-MUI/V/2010

TERHADAP AKAD MURABAHAH PADA PRODUK CICIL EMAS DI BANK SYARIAH MANDIRI

Annas Syams Rizal Fahmi, Muhammad Irkham Firdaus, May Shinta 


\section{Abstract}

Sharia banks have the function of collecting funds from the public in the form of deposits and investments from the owner of the funds. New strategies have been developed and introduced to the Islamic banking industry. As a form of respondent to the community's needs, Sharia Bank provides services to customers in the form of financial services to convert existing (conventional) non-Sharia transactions to transactions that are in accordance with Sharia by providing financing services for gold installment products that are based on the basis of law on the Fatwa of the National Sharia Council. In this study the authors discuss the Murabahah Financing Analysis on Gold Installment Products in terms of the Application of the MUI DSN Fatwa No: 77 / DSN-MUI / V / 2010. So that it is expected to be able to know how the mechanism concept of implementing the contract in financing the gold installment product and also the foundation of the MUI DSN Fatwa. In this study the authors used qualitative methods. As for obtaining data on employees and customers who finance gold installment products, the authors do 3 ways, namely by using observation, interviews and documentation, the data collected is then analyzed using descriptive analysis methods. The results of this study indicate that the practice of murabahah financing on gold installment products at Bank Syariah Mandiri Ponorogo Sub-Branch Offices is in accordance with the DSN MUI fatwa No: 77 / DSN-MUI / V / 2010 concerning the sale and purchase of gold by cash. The fact is that in the practice of gold installments at Bank Syariah Mandiri Ponorogo Sub-Branch Offices, the price of gold does not increase as long as the contract runs even though there is an extension of time after maturity, gold is used as collateral with the rahn contract and stored at Bank Syariah Mandiri Ponorogo Sub-Branch Office, gold which is used as collateral is not changed the contract and did not change ownership and remained in the safe of Bank Syariah Mandiri Ponorogo Sub-Branch Office.

Keywords: Fatwa DSN MUI, Murabahah Financing, Gold Installment Products

\section{A. PENDAHULUAN}

Perkembangan bank syariah di Indonesia merupakan perwujudan dari permintaan masyarakat yang membutuhkan suatu sistem perbankan alternatif yang selain menyediakan jasa perbankan atau keuangan yang sehat juga memenuhi prinsip-prinsip syariah. Perbankan syariah merupakan suatu sistem perbankan yang didasarkan pada hukum Islam, dimana timbulnya sistem perbankan syariah ini didasari oleh larangan dalam ajaran agama Islam yaitu memungut bunga dalam meminjam uang atau yang biasa disebut dengan riba seperti dipraktikkan oleh bank konvensional (Iskandar,

IMPLEMENTASI FATWA DSN-MUI NO: 77/DSN-MUI/V/2010 
2013: 36). Salah satu aktivitas perbankan syariah adalah menyalurkan pembiayaan kepada nasabahnya.

Dasar hukum pembiayaan oleh bank syariah terdapat di dalam Undang-Undang Nomor 21 Tahun 2008 tentang Perbankan Syariah (Selanjutnya disebut UU Perbankan Syariah). Menurut undang-undang ini yang dimaksud dengan prinsip syariah adalah prinsip hukum Islam dalam kegiatan perbankan berdasarkan fatwa yang dikeluarkan oleh lembaga yang memiliki kewenangan dalam penerapan fatwa di bidang syariah (Iskandar, 2013: 36).

Pada Pasal 1 ayat (25) UU Perbankan Syariah menyatakan bahwa pembiayaan adalah penyediaan dana atau tagihan yang dipersamakan dengan itu berupa:

1. Transaksi investasi dalam bentuk Mudharabah dan musyarakah;

2. Transaksi sewa-menyewa dalam bentuk ijarah atau sewa beli dalam bentuk ijarah muntahiyah bittamlik;

3. Transaksi jual beli dalam bentuk piutang murabahah, salam, dan istishna';

4. Transaksi pinjam meminjam dalam bentuk hutang piutang qardh; dan

5. Transaksi sewa-menyewa jasa dalam bentuk ijarah untuk transaksi multijasa (Undang-Undang Republik Indonesia Nomor 21 Tahun 2008 Tentang Perbankan Syariah).

Perbankan syariah dalam melakukan kegiatannya harus berdasarkan prinsip syariah, demokrasi ekonomi, dan prinsip kehatihatian. Tujuan perbankan syariah menurut pasal 3 UU Perbankan Syariah bertujuan menunjang pelaksanaan pembangunan nasional dalam rangka meningkatkan keadilan, kebersamaan, dan pemerataan kesejahteraan rakyat (Muthaher, 2012:14).

Pembiayaan merupakan salah satu tugas pokok bank, yaitu pemberian fasilitas penyediaan dana untuk memenuhi kebutuhan pihak-pihak yang merupakan defisit unit. Menurut sifat penggunaannya, pembiayaan dibagi menjadi dua hal berikut:

1. Pembiayaan produktif, yaitu pembiayaan yang ditujukan untuk memenuhi kebutuhan produksi dalam arti luas, yaitu untuk peningkatan usaha, baik usaha produksi, perdagangan maupun investasi.

IMPLEMENTASI FATWA DSN-MUI NO: 77/DSN-MUI/V/2010 TERHADAP AKAD MURABAHAH PADA PRODUK CICIL EMAS DI 
2. Pembiayaan konsumtif, yaitu pembiayaan yang digunakan untuk memenuhi kebutuhan konsumsi, yang akan habis digunakan untuk memenuhi kebutuhan (Antonio, 2001:160).

PT. Bank Syariah Mandiri hadir dan tampil dengan harmonisasi idealisme usaha dengan nilai-nilai spiritual. Bank Syariah Mandiri tumbuh sebagai bank yang mampu memadukan keduanya, yang melandasi kegiatan operasionalnya. Harmonisasi idealisme usaha dan nilai-nilai spiritual inilah yang menjadi salah satu keunggulan Bank Syariah Mandiri dalam kiprahnya di perbankan Indonesia (www.mandirisyariah.co.id).

Salah satu aktivitas PT Bank Syariah Mandiri adalah membantu nasabah untuk membiayai pembelian atau Kepemilikan Emas yaitu pembiayaan jual beli emas secara tidak tunai pada perbankan syariah yang memberikan kesempatan kepada nasabah untuk memiliki emas batangan dengan cara pembayaran secara mencicil.

Produk Cicil Emas adalah salah satu produk yang dikeluarkan oleh Bank Syariah Mandiri sejak 25 Maret 2013 yang merupakan produk kepemilikan emas untuk masyarakat. Produk Cicil Emas memberikan kesempatan masyarakat untuk memiliki emas batangan dengan cara mencicil dengan menggunakan akad murabahah dengan jaminan diikat dengan rahn (gadai) dengan berat minimal 10 gram hingga 250 gram.

Dewan Syariah Nasional Majelis Ulama Indonesia (DSN-MUI) telah mengeluarkan Fatwa Terkait Tentang Cicil Emas No 77/DSNMUI/ V/2010 Tentang Jual Beli Emas Secara Tidak Tunai. Hal ini kemudian dimanfaatkan oleh BSM demi menjawab kebutuhan masyarakat akan produk investasi. Emas merupakan barang dengan demand yang tinggi baik untuk proteksi aset, kepentingan berjaga, kebutuhan tabungan haji, maupun investasi. Harga emas di dunia dalam jangka panjang cenderung naik, hampir setiap lima tahun harga emas naik minimal 100 persen.

Dari berbagai macam produk yang ada di BSM produk Cicil Emas adalah produk yang paling diminati oleh masyarakat, karna syaratsyarat yang mudah, juga dengan adanya jaminan, karena masyarakat lebih tertarik oleh produk yang mudah difahami dan jaminan yang tidak terlalu besar untuk memudahkan membeli emas tersebut.

\section{Rumusan Masalah}

IMPLEMENTASI FATWA DSN-MUI NO: 77/DSN-MUI/V/2010

4

TERHADAP AKAD MURABAHAH PADA PRODUK CICIL EMAS DI

BANK SYARIAH MANDIRI

Annas Syams Rizal Fahmi, Muhammad Irkham Firdaus, May Shinta

Retnowati dan Zulfatus Sa'diah 
Berdasarkan analisis latar belakang masalah yang tertera diatas, maka dapat dikemukakan rumusan masalah sebagai berikut:

1. Bagaimana Praktik Pembiayaan Murabahah pada Produk Cicil Emas di Bank Syariah Mandiri Kantor Cabang Pembantu Ponorogo?

2. Bagaimana Penerapan Fatwa DSN MUI No: 77/DSN-MUI/V/2010 terhadap Produk Cicil Emas di Bank Syariah Mandiri Kantor Cabang Pembantu Ponorogo?

\section{B. PENELITIAN TERDAHULU}

1. Evi Yatun Ruaida, dalam penelitian skripsinya, Analisis Yuridis Akad Pembiayaan Kepemilikan Emas Menurut Fatwa Nomor: 77/Dsn-Mui/V/2010 Tentang Jual Beli Emas Secara Tidak Tunai (Studi pada Bank Syariah Mandiri Cabang Bandar Lampung), hasil penelitian ini adalah Syarat dan ketentuan transaksi jual beli emas secara tidak tunai menurut Fatwa Nomor: 77/DSNMUI/V/2010 pada perbankan syariah adalah emas tidak menjadi alat tukar yang resmi (uang), harga jual (tsaman) tidak boleh bertambah selama jangka waktu perjanjian meskipun ada perpanjangan waktu setelah jatuh tempo, emas yang dibeli dengan pembayaran tidak tunai boleh dijadikan jaminan ( $\mathrm{rahn}$ ) dan emas yang dijadikan jaminan tidak boleh dijual belikan atau dijadikan objek akad lain yang menyebabkan perpindahan kepemilikan.

2. Dewi Sinta Sumanti, dalam penelitian skripsinya, Prosedur Pembiayaan Produk Cicil Emas Pada Bank Syariah Mandiri Kantor Cabang Bandar Jaya, hasil penelitian ini adalah prosedur pembiayaan cicil emas adalah sebagai berikut: permohonan nasabah, pembuatan NAP, persetujuan pembiayaan, akad, Pengadaan Emas, dan penyimpanan agunan. Prosedur sudah sesuai dengan Fatwa DSN MUI No: 04/DSN-MUI/IV/2000 tentang murabahah.

3. Mariana Abdullah, dalam penelitian skripsinya, Penerapan Fatwa DSN MUI Tentang Produk Cicil Emas Di Bsm Cirendeu (Studi Kasus di Bank Syariah Mandiri Kantor Cabang Pembantu Cirendeu), hasil dari penelitian tersebut adalah adanya kesepakatan diawal untuk jumlah angsuran nasabah dikalihkan

IMPLEMENTASI FATWA DSN-MUI NO: 77/DSN-MUI/V/2010 TERHADAP AKAD MURABAHAH PADA PRODUK CICIL EMAS DI 
dengan masa angsuran nasabah dan dana pertama yang dikeluarkan sebelumnya itu sudah diketahui diawal kesepakatan. Jadi tidak ada penambahan harga walaupun nasabah memintah adanya perpanjangan waktu, karena di dalam cicil emas tidak ada perpanjangan waktu setelah jatuh tempo artinya setelah jatuh tempo selesai maka emasnya harus diambil dan tidak bisa di perpanjang lagi.

4. Ori Fiska Soviah, dalam penelitian skripsinya, Strategi Door To Door Marketing Pada Produk Pembiayaan Cicil Emas Di Bank Syariah Mandiri Kcp Cirendeu, hasil dari penelitian tersebut adalah Berdasarkan temuan dan pembahasan dari penelitian ini dapat disimpulkan bahwa strategi door to door marketing pembiayaan produk cicil emas di Bank Syariah Mandiri KCP Cirendeu kurang maksimal dalam memasarkan produk cicil emas, karena strategi yang dilakukan di Bank Syariah Mandiri (nasabah existing dan persone by community), dianggap kurang efektif oleh penulis, ini di buktikan dengan target capaian sebesar 700 juta di tahun 2019 sedangkan yang dicapai pada tahun 2019 hanya sebesar 500 juta.

5. Gusti Muslihuddin Sa'adi, dalam penelitian jurnalnya, Analisa Kritis Hukum Kredit Emas (Kajian Kritis terhadap Fatwa DSNMUI Nomor 77 Tahun 2010 Tentang Murabahah Emas), , hasil dari penelitian ini adalah pengaruh hilangnya 'illat tersebut terhadap hukum jual-beli emas secara kredit, penulis berpendapat bahwa 'illat mustanbathah tidak dapat membatalkan hukum ashl, sehingga ada ataupun tidaknya illat tsamaniyah pada emas tidak mempengaruhi hukum emas sebagai amwal ribawiyah, sehingga hukum jual-beli dengan kredit tetaplah haram sesuai hadis Ubadah bin Shamit R.A.

\section{LANDASAN TEORI}

1. Al-murabahah

Kata al-Murabahah diambil dari bahasa Arab dari (الرح) yang berarti kelebihan dan tambahan (keuntungan), murabahah juga berati Al-Irbaah karena salah satu dari dua orang yang bertransaksi memberikan keuntungan kepada yang lainnya (Karim, 2014:113). 
Murabahah adalah menjual barang dengan harga jelas, sehingga boleh dipraktekan dalam transaksi jual beli. Contohnya adalah jika seseorang berkata, "aku menjual barang ini dengan harga seratus sepuluh" dengan begitu, keuntungan yang diambilnya jelas. Ini tak jauh beda dengan mengatakan, "berilah aku keuntungan sepuluh dirham" (Wahbah Az-Zuhaili, 2011:358).

2. Fatwa DSN MUI No: 77/DSN-MUI/V/2010 FATWA JUAL BELI EMAS SECARA TIDAK TUNAI

Jual beli emas secara tidak tunai, baik melalui jual beli biasa atau jual beli murabahah, hukumnya boleh (mubah, ja'iz) selama emas tidak menjadi alat tukar yang resmi (uang). Batasan dan Ketentuan, sebagai berikut:

1. Harga jual (tsaman) tidak boleh bertambah selama jangka waktu perjanjian meskipun ada perpanja-ngan waktu setelah jatuh tempo.

2. Emas yang dibeli dengan pembayaran tidak tunai boleh dijadikan jaminan (rahn).

3. Emas yang dijadikan jaminan sebagaimana dimaksud dalam angka 2 tidak boleh dijualbelikan atau dijadikan obyek akad lain yang menyebabkan perpindahan kepemilikan

Fatwa ini berlaku sejak tanggal ditetapkan dengan ketentuan jika di kemudian hari ternyata terdapat kekeliruan, akan diubah dan disempurnakan sebagaimana mestinya.

\section{METODE PENELITIAN}

Jenis penelitian yang digunakan adalah Kualitatif Deskriptif. Jenis penelitian ini lebih relevan dengan judul yang akan diteliti dan sesuai untuk jawaban semua yang berkaitan dengan fokus penelitian. Penelitian deskriptif adalah jenis penelitian dengan cara menggambarkan data-data yang telah terkumpul sebagaimana adanya tanpa bermaksud membuat kesimpulan yang berlaku untuk umum atau generalisasi (Sugiyono, tt: 23).

a. Sumber Data yang dipakai pada penelitian ini adalah:

1) Data premier adalah hasil wawancara dengan manajer PT. Bank Syariah Mandiri Kantor Cabang Ponrogo. 
2) Data sekunder diperoleh dari hasil dokumentasi baik berupa soft file, maupun dokumen lain yang terkait dengan fokus penelitian.

b. Tekhnik Pengumpulan Data

Dalam pengumpulan data untuk memperoleh data yang valid penyusun ingin meneliti dengan menggunakan beberapa teknik dalam pengumpulan datanya, adapun teknik - teknik tersebut antara lain: Wawancara, Observasi, dan Dokuentasi.

c. Tekhnik Analisa Data

Untuk analisis data yang digunakan peneliti adalah analisis Model Miles dan Huberman. Analisis data penelitian kualitatif, dapat dilakukan melalui langkah-langkah antara lain: Reduksi Data, Penyajian Data (Data Display), Mengambil Data Lalu diVerifikasi Patilima (Patilima, 2007:87).

\section{E. HASIL DAN PEMBAHASAN}

Dari hasil wawancara tersebut peneliti dapat menyimpulkan bahwa penerapan Fatwa DSN MUI No: 77/DSN-MUI/V/2010 terhadap Produk Cicil Emas di Bank Syariah Mandiri Kantor Cabang Pembantu Ponorogo telah menerapkan bahwa Harga jual (tsaman) tidak bertambah selama jangka waktu perjanjian meskipun ada perpanjangan waktu setelah jatuh tempo, dan Emas yang dibeli dengan pembayaran angsuran dijadikan jaminan ( $\mathrm{rahn}$ ), dan emas yang dibeli nasabah tidak diperjualbelikan atau dijadikan objek akad sehingga berpindah kepemilikan. Dalam hal ini penerapan yang dilakukan oleh Bank Syariah Mandiri Kantor Cabang Pembantu Ponorogo telah sesuai dengan fatwa DSN MUI No: 77/DSN-MUI/V/2010 tentang jual beli emas secara tidak tunai.

Dalam pembiayaan produk cicil emas proses yang harus dilakukan oleh nasabah adalah dengan membuka rekening di Bank Syariah Mandiri Kantor Cabang Pembantu Ponorogo, kemudian pihak Bank Syariah Mandiri yang bertanggung jawab dalam produk cicil emas akan menjelaskan produk cicil emas, dan nasabah mempersiapkan syarat-syarat, uang muka $20 \%$ dan uang administrasi sebesar $1 \%$, dan dilakukanlah tanda tangan akad pembiayaan produk cicil emas dan pihak bank akan memesan emas sesuai permintaan nasabah, kemudian pihak bank akan membuatkan SBKE (surat bukti 
kepemilikan emas) dan menyimpannya beserta emas di brankas hasanah Bank Syariah Mandiri Kantor Cabang Pembantu Ponorogo.

Dalam penerapan akad Bank Syariah Mandiri Kantor Cabang Pembantu Ponorogo sudah sesuai dengan dengan fatwa DSN MUI No: 77/DSN-MUI/V/2010 tentang jual beli emas secara tidak tunai, karena emas yang di angsur oleh nasabah tidak akan bertambah harganya selama masa angsuran berlangsung, selama angsuran berlangsung emas akan disimpan dalam brankas hasanah Bank Syariah Mandiri Kantor Cabang Pembantu Ponorogo menjadi jaminan atau agunan dengan akad rahn dan akan dikembalikan kepada nasabah apabila sudah selesai dalam masa angsurannya atau nasabah sudah melunasi semua angsurannya, selama emas berada di brankas hasanah Bank Syariah Mandiri Kantor Cabang Pembantu Ponorogo emas tidak akan berpindah kepemilikan atau berganti akad dan tetap pada akad pertama.

Dalam pembiayaan produk cicil emas penerapan denda di Bank Syariah Mandiri Kantor Cabang Pembantu Ponorogo dilaksanakan karena mengikuti peraturan BI (Bank Indonesia), untuk denda dilaksanakan hanya untuk kedisiplinan nasabah dalam menjalani angsuran dan dapat dicabut apabila nasabah sudah memenuhi kewajibannya, karena dalam syariat islam tidak diperbolehkannya denda

Dalam penerapan fatwa DSN MUI No: 77/DSN-MUI/V/2010 tentang jual beli emas secara tidak tunai di Bank Syariah Mandiri Kantor Cabang Pembantu Ponorogo tidak terdapat kendala karena Bank Syariah Mandiri menjadikan fatwa DSN MUI No: 77/DSNMUI/V/2010 tentang jual beli emas secara tidak tunai sebagai landasan hukum dalam transaksinya.

Dalam praktik pembiayaan produk cicil emas ketika nasabah akan mengambil pembiayaan tersebut pihak bank tidak menjelaskan secara detail produk tersebut bahkan ada beberapa nasabah tidak dijelaskan sama sekali, dan nasabah tidak mendapatkan penjelasan mengenai fatwa DSN MUI bahkan beberapa nasabah tidak mengetahui apa itu fatwa DSN MUI karena pihak bank tidak menjelaskan produknya secara mendetail.

Dalam penelitian yang disebutkan dalam fatwa dari Nasional No. 77/DSN-MUI/7/2010, menurut Ibnu Taimiyah dan Ibnu Al-Qayyim,

IMPLEMENTASI FATWA DSN-MUI NO: 77/DSN-MUI/V/2010 TERHADAP AKAD MURABAHAH PADA PRODUK CICIL EMAS DI BANK SYARIAH MANDIRI 
mereka sepakat untuk mengungkapkan argumennya bahwa emas dan perak adalah komoditas yang dijual dan dibeli sesuai dengan apa yang terjadi pada komoditas, dan mereka tidak lagi memiliki harga, karena kebutuhan masyarakat sangat mendesak. Untuk menjual dan membelinya, jika tidak diizinkan menjualnya dengan cara mencicil, kepentingan orang-orang menjadi rusak, dan mereka akan mengalami kesulitan. Sekiranya pintu (jual beli emas secara angsuran) ini ditutup, maka tertutuplah pintu utang piutang masyarakat akan mengalami kesulitan yang tidak terkira.

\section{F. KESIMPULAN}

Berdasarkan pembahasan yang telah dilakukan oleh peneliti mengenai Analisis Pembiayaan Murabahah pada Produk Cicil Emas ditinjau dari Penerapan Fatwa DSN MUI No: 77/DSN-MUI/V/2010, (Studi Kasus di Bank Syariah Mandiri Kantor Cabang Pembantu Ponorogo), peneliti dapat mengambil kesimpulan untuk menjawab rumusan masalah, bahwa:

1. Dalam praktik murabahah di Bank Syariah Mandiri Kantor Cabang Pembantu Ponorogo nasabah akan memberikan uang muka kepada pihak bank sebesar $20 \%$ harga emas kemudian bank akan menambahkan sisanya $80 \%$ dan membelikan emas, nasabah akan mendapatkan berupa fotokopi SBKE (Surat Bukti Kepemilikan Emas), surat yang asli akan disimpan bersama emas dibrankas hasanah Bank Syariah Mandiri Kantor Cabang Pembantu Ponorogo sampai nasabah melunasi semua angsuran yang sudah ditetapkan bersama ketika tanda tangan akad berlangsung dan itu sudah sesuai dengan Fatwa DSN MUI No: 77/DSN-MUI/V/2010 tentang jual beli emas secara tidak tunai, dan menjadikan emas sebagai jaminan atau agunan dengan ber akad rahn dan disimpan di brankas hasanah Bank Syariah Mandiri Kantor Cabang Pembantu Ponorogo.

2. Dalam penerapan Fatwa DSN MUI No: 77/DSN-MUI/V/2010 tentang jual beli emas secara tidak tunai di Bank Syariah Mandiri Kantor Cabang Pembantu Ponorogo sebagai berikut:

a. Harga jual tidak akan bertambah atau berkurang selama masa angsuran meskipun terjadi jatuh tempo karena harga emas ditetapkan pada hari ketika akad berlangsung. 
b. Emasnya dijadikan jaminan selama masa angsuran. Artinya emas tersebut disimpan di Bank sampai masa angsurannya telah selesai maka emas tersebut bisa dimiliki oleh nasabah.

c. Emas yang sudah di jadikan jaminan tidak bisa dijadikan jaminan lagi karena sudah dijadikan jaminan pada akad pertama artinya barang yang sudah di jaminkan tidak bisa dijaminkan untuk yang kedua.

\section{G. UCAPAN TERIMA KASIH}

1. Bagi pihak Bank Syariah Mandiri Kantor Cabang Pembantu Ponorogo agar lebih jelas lagi dalam menjelaskan produk-produk yang terdapat di Bank Syariah Mandiri karena nasabah membutuhkan pemahaman tersebut dan untuk lebih meningkatkan lagi kualitas pelayanan untuk nasabah guna kenyamanan dan kepercayaan nasabah kepada Bank Syariah Mandiri Kantor Cabang Pembantu Ponorogo dan selalu menjunjung tinggi syariat Islam.

2. Penulis memberikan rekomendasi penelitian ini dapat digunakan sebagai bahan pertimbangan bagi peneliti yang akan datang untuk meneliti akad rahn dalam cicil emas dan hukum islam jika ada akad tambahan dalam satu transaksi.

\section{DAFTAR PUSTAKA}

Abdullah, M. (2019). Penerapan Fatwa DSN MUI Tentang Produk Cicil Emas Di BSM Cirendeu. Universitas Muhamadiyah Jakarta.

Antonio, M. S. (2001). Bank Syariah dan Teori Praktik. Jakarta: Gema Insani.

Iskandar, S. (2013). Bank dan Lembaga Keuangan Lainnya. Jakarta: In Media.

Karim, A. A. (2014). Bank Islam Analisis Fiqih dan Keuangan. Jakarta: Raja Grafindo.

Muthaher, O. (2012). Akuntansi Perbankan Syariah. Yogyakarta: Graha Ilmu.

Patilima, H. (2007). Metode Penelitian Kualitatif. Bandung: Alfabeta.

Profil PT.Bank Syariah Mandiri, https://www.mandirisyariah.co.id/tentang-kami/profilperusahaan, diakses pada tanggal 1 Maret jam 19.57. 
Ruaida, E. Y. (2017). Analisis Yuridis Akad Pembiayaan Kepemilikan Emas Menurut Fatwa Nomor: 77/DSN-MUI/V/2010 Tentang Jual Beli Emas Secara Tidak Tunai (Studi pada Bank Syariah Mandiri Cabang Bandar Lampung). Universitas Lampung.

Sa'adi, G. M. (2019). Analisa Kritis Hukum Kredit Emas (Kajian Kritis terhadap Fatwa DSNMUI Nomor 77 Tahun 2010 Tentang Murabahah Emas). Jurnal At-Taradhi Vol. 10 (1).

Sugiyono. (t.t). Metode Penelitian Kuantitatif, Kualitatif dan R\&D. Bandung: Alfabeta.

Soviah, O. F. (2020). Strategi Door To Door Marketing Pada Produk Pembiayaan Cicil Emas Di Bank Syariah Mandiri KCP Cirendeu. Universitas Muhamadiyah Jakarta.

Sumanti, D. S. (2014). Prosedur Pembiayaan Produk Cicil Emas Pada Bank Syariah Mandiri Kantor Cabang Bandar Jaya. Insitut Agama Islam Metro, Lampung.

Undang-Undang Republik Indonesia Nomor 21 Tahun 2008 Tentang Perbankan Syariah

Wahbah Az- Zuhaili. (2011). Fiqih Islam Wa Adilatuhu Jilid 5. Jakarta: Gema Insani.

Wahbah Az- Zuhaili. (1985). Fiqih Islam Wa Adilatuhu Jilid 4. Damaskus: Dar El Fikr. 